\title{
STRATEGI HUMAS DALAM MENJALIN GOOD RELATIONSHIP DENGAN EXTERNAL STAKEHOLDERS UAD
}

\author{
Oleh: Dewi Soyusiawaty dan Choirul Fajri \\ Pengajar Universitas Ahmad Dahlan \\ E-mail: choirulfajri@yahoo.co.id
}

\begin{abstract}
Hubungan baik antara organisasi dengan stakeholders sangat diperlukan untuk mendukung kesuksesan organisasi.. UAD sebagai salah satu organisasi pendidikan, telah menempatkan fungsi humas dalam berbagai peranan, termasuk dalam menjalankan fungsi pencitraan dan menjalin hubungan baik tersebut. Penelitian ini bertujuan untuk mengetahui strategi yang bisa dilakukan humas untuk menjalin hubungan baik dengan stakeholders external, terkait dengan sinergitas diantara keduanya. Dalam melakukan penelitian ini, peneliti akan menggunakan metode studi kasus. Pemilihan metode studi kasus, dilakukan untuk mengetahui bagaimana peranan maupun strategi-strategi humas yang bisa dijalankan untuk membangun kedekatan dengan stakeholders external. Adapun teknik pengumpulan dalam penelitian ini adalah dengan menggunakan wawancara, serta focus group discussion dengan para stakeholders external UAD. Hasil yang diharapkan dalam penelitian ini adalah publikasi ilmiah dalam bentuk jurnal dan mendapatkan pengakuan Hak Kekayaan Interlektual (HAKI). Selain itu, penelitian ini juga diharapkan mampu memberikan gambaran mengenai strategi-strategi humas yang bisa dijalankan ke depannya, untuk menjalin hubungan baik dengan stakeholders external.
\end{abstract}

\section{A. PENDAhULUAN}

Publik mempunyai peranan penting dalam menunjang kesuksesan setiap organisasi, baik itu intenal maupun eksternal. Tujuan organisasi hanya akan tercapai apabila ada dukungan dari masing-masing publik. Oleh karenanya, menjaga hubungan baik dengan setiap publik, menjadi sebuah kebutuhan yang harus dilakukan. Masingmasing publik, tentu mempunyai harapan yang berbeda-beda terhadap organisasi. Di sinilah seorang humas (public relations) dibutuhkan, untuk dapat mensinergiskan hal itu.

Adanya perbedaan karakteristik dari publik internal dan external tentu memerlukan strategi yang berbeda pula dalam menjaga kesinambungan diantara keduanya. Secara organisatoris, public exterrnal berada di luar organisasi dan tidak memiliki keterkaitan secara langsung. Oleh karenanya, justru tekanan-tekanan yang diberikan oleh publik external ini jauh lebih besar dibandingan dengan publik internal. Misalnya saja pada pemberitaan-pemberitaan di media massa, beberapa diantara media massa memuat pemberitaan UAD secara tidak berimbang bahkan terkesan menyudutkan.

Hal tersebut, bisa dilihat saat terjadinya aksi demonstrasi para mahasiswa UAD beberapa waktu lalu. Saat itu UAD, menjadi sorotan banyak media. Ada yang memberitakan secara netral dengan menyatakan bahwa masalah demonstrasi merupakan sebuah hal yang wajar dilakukan para mahasiswa, namun tidak sedikit pula yang bernada 
negatif dan cenderung menjatuhkan. Berikut diantara judul-judul pemberitaan di media massa, pada saat itu: Mahasiswa UAD tuntut peningkatan fasilitas kampus dalam Tribun Yogya Kamis 26 Februari 2015, Fasilitas Kurang Memadai Mahasiswa UAD Demo dalam Jejaring Net 04 Maret 2015, maupun Kuliah di Panti Mahasiswa UAD Demo dalam Solo Pos Kamis 26 Februari 2015.

Public Relations sebagai sebuah fungsi manajemen yang menjadi jembatan komunikasi antara organisasi dengan publiknya tentu mempunyai peranan dalam mengatasi hal-hal tersebut. Adanya pemberitaan negatif di media yang disebar luaskan kepada masyarakat luas, tentu menjadi sebuah perhatian besar yang harus ditanggulani, mengingat citra organsisasi sebagai taruhannya. Oleh karenanya, strategi-strategi untuk menjalin kedekatan dengan media menjadi sebuah langkah yang bisa dilakukan, untuk menciptakan publisitas yang bagus mengenai UAD sendiri. Dengan adanya hubungan baik dengan media, maka isu-isu negatif yang sedang berkembang tentu dapat diminimalisir.

Tidak hanya dengan media, namun juga dengan pihak-pihak external lainnya hubungan baik (good relationship) tersebut dapat dikembangkan, baik itu pemerintah selaku memegang kebijakan tertinggi, organisasi/perguruan tinggi lainnya, rekanan/mitra UAD, maupun masyarakat. Dengan adanya hubungan baik tersebut, memungkinkan terciptanya kerjasama yang baik pula untuk mencapai tujuan dari organisasi pada khususnya, dan kepentingan dari publik external terhadap organisasi sendiri pada umumnya.

Penelitian ini merupakan penelitian lanjutan, dari penelitian sebelumnya yakni mengenai strategi humas dalam meningkatkan loyalitas stakeholders internal UAD. Hasil penelitian tersebut, menunjukkan bahwa banyak harapan dari para stakeholders internal terhadap Humas UAD untuk meningkatkan loyalitas mereka. Harapan dari para stakeholders internal tersebut, kemudian dijadikan bahan penyusunan program kerja dari Humas UAD sendiri. Mengingat obyek kerja dari Humas UAD tidak hanya para stakeholders internal saja, namun juga external. Maka peneliti merasa perlu, untuk melakukan penelitian lanjutan guna mengetahui hal-hal apa saja yang perlu dilakukan untuk menjaga hubungan baik dengan stakeholders external (pemerintah, media, Organisasi Muhammadiyah sendiri, Amal Usaha Muhammadiyah, instusi lain/rekanan $\mathrm{UAD}$, maupun perguruan tinggi lain).

\section{B. TINJAUAN PUSTAKA}

\section{Peran Public Relations}

Peran profesi public relations semakin bias tanpa adanya spesialisasi profesi sehingga diharapkan seorang praktisi PR memahami perannya dengan baik, bukan hanya sekedar pelengkap kerja dan pekerjaan yang merangkap seorang sekretaris direksi. Konsep peranan petugas PR yang dikembangkan oleh Broom, kemudian dikembangkan oleh Bromm dan Smith (Dozier, 1992), di mana peran PR merupakan salah satu kunci penting untuk pemahaman fungsi PR dan komunikasi organisasi. Ada beberapa fungsi dominan yang harus dilaksanakan seorang PR sejati antara lain berperan sebagai: 
Diterbitkan oleh Program Studi IImu Komunikasi

Universitas Ahmad Dahlan Yogyakarta

\section{a) Technician communication}

Kebanyakan praktisi masuk ke bidang ini sebagai teknisi komunikasi. Deskripsi kerja dalam lowongan pekerjaan biasanya menyebutkan keahlian komunikasi dan jurnalistik, sebagai syarat. Teknisi komunikasi disewa untuk menulis dan mengedit newsletter karyawan, menulis news release dan feature, mengembangkan isi web, dan menangani kontak media. Praktisi yang melakukan peran ini biasanya tidak hadir disaat manajemen mendefinisikan problem dan memilih solusi. Mereka baru bergabung untuk melakukan komunikasi dan mengimplementasikan program, terkadang tanpa mengetahui secara menyeluruh motivasi atau tujuan yang diharapkan. Meskipun mereka tidak hadir saat diskusi tentang kebijakan baru atau keputusan manajemen baru, merekalah yang diberi tugas untuk menjelaskannya kepada karyawan dan pers.

b) Expert Prescriber communication

Ketika para praktisi mengambil peran sebagai pakar/ahli, orang lain akan menganggap mereka sebagai otoritas dalam persoalan PR dan solusinya. Manajemen puncak menyerahkan PR di tangan para ahli dan manajemen biasanya mengambil peran pasif saja. Praktisi yang beroperasi sebagai praktisi pakar bertugas mendefinisikan problem, mengembangkan program, dan bertanggung jawab penuh atas implemetasinya.

c) Communication facilitator

Peran fasilitator komunikasi bagi seorang praktisi adalah sebagai pendengar yang peka dan broker (perantara) komunikasi. Fasilitator komunikasi bertindak sebagai perantara (liason), interpreter, dan mediator antara organisasi dan publiknya. Mereka menjaga komunikasi dua arah dan memfasilitasi percakapan dengan menyingkirkan rintangan dalam hubungan dan menjaga agar saluran komunikasi tetap terbuka. Tujuannya adalah memberi informasi yang dibutuhkbaik itu manajemen maupun publik untuk membuat keputuasan demi kepentingan bersama. Praktisi yang berperan sebagai fasilitator komunikasi ini bertindak sebagai sumber informasi dan agen kontak resmi antara organisasi dan publik. Mereka menengahi interaksi, menyusun agenda mendiagnosis dan memperbaiki kondisi-kondisi yang menganggu hubungan komunikasi di antara kedua belah pihak. Fasilitator komunikasi menempati peran di tengah-tengah dan berfungsi sebagai penghubung antara organisasi dan publik.

d) Fasilitator Pemecah Masalah

Ketika praktisi melakukan peran ini, mereka berkolaborasi dengan manajer lain untuk mendefinisikan dan memecahkan masalah. Mereka menjadi bagian dari tim perencanaan strategies. Kolaborasi dan musyawarah dimulai dengan persoalan pertama dan kemudian sampai ke evaluasi program final. Praktisi pemecah masalah membantu manajer lain untuk dan organisasi untuk mengaplikasikan PR dalam proses manajemen bertahap yang juga dipakai untuk memecahkan problem organisasional lainnya. 


\section{Komunikasi dengan Stakeholders}

Stakeholders eksternal juga merupakan pihak yang mempunyai keterkaitan langsung dengan organisasi. Oleh karenanya menjalin komunikasi yang baik dengan mereka adalah sebuah keharusan. Setiap organisasi hendaknya mempunyai strategi khusus, guna menjalin komunikasi dengan para stakeholders eksternal tersebut. Dalam penelitian ini, stakeholders eksternal tersebut adalah pemerintah dan komunitas.

\section{a. Hubungan dengan pemerintah}

Di dalam suatu negara, pemerintah mempunyai peranan penting terutama dalam kaitannya dengan masalah regulasi. Oleh karenanya organisasi mulai menyadari bahwa daripada memerangi regulasi, sebuah pendekatan yang lebih efektif adalah membela posisi-posisi mereka kepada para pembuat keputusan. Organisasi mulai melindungi kepentingan mereka dengan taktik-taktik lobi dan negosiasi yang dikemas dengan baik, terutama ketika menghadapi oposisi yang substansial dari kelompok konsumen maupun komunitas. (Argenti, 2010: 271)

Dari hal di atas, menyiratkan betapa pentingnya organisasi untuk menjaga hubungan baik dengan pemerintah. Setiap organisasi hendaknya menggunakan berbagai taktik untuk melakukan pendekatan dengan pemerintah. Tidak hanya dengan kemampuan lobi dan negosiasi semata, namun juga agar program, yang dibuat oleh organisasi mampu mendapatkan dukungan dari pemerintah.

Adapun bentuk-bentuk yang dapat dilakukan dalam kaitannya dengan membina hubungan baik dengan pemerintah, misalnya saja: mengirimkan surat ucapan selamat bila instansi yang bersangkutan berulang tahun, mengirimkan kalender atau agenda, mengadakan olah raga bersama, dan lainnya. (Effendy, 2011:137)

Menurut Argenti (2010, 275-279), ada beberapa aktivitas spesifik yang digunakan organisasi untuk meningkatkan posisi mereka dengan para legislatif, berikut diantaranya:

1. Pembangunan koalisi

Dengan membangun koalisasi dengan organisasi-organisasi lainnya ataupun dengan membentuk asosiasi organisasi sejenis, maka kekuatan organisasi untuk memberikan tekanan kepada pemerintah dapat lebih kuat. Selain itu juga akan ada kesempatan yang baik untuk mempengaruhi hasil-hasil legislatif dibanding bertindak sendirian.

2. Keterlibatan pemimpin di dalam hubungan pemerintah

Pemimpin merupakan pucuk tertingi dalam sebuah organisasi, pelibatan pemimpin dalam menjalin hubungan dengan pemerintah adalah sebuah keharusan. Dengan demikian, pemimpin akan mengenal orang-orang yang ada di dalam legislatif sehingga mempunyai kedekatan emosional guna meminta dukungan mereka terkait pengembangan organisasi.

3. Melobi pada basis individu

Lobi merupakan sebuah aktivitas yang ditujukan sebagai promosi melalui sistem komunikasi yang terkoordinir dengan para pembuat kebijakan utama. 
Diterbitkan oleh Program Studi IImu Komunikasi

Universitas Ahmad Dahlan Yogyakarta

Melakukan lobi dengan menggunakan individu merupakan sebuah metode paling tepat untuk dapat terlibat di dalam politik.

4. Komite aksi politik

Metode lain yang dapat digunakan untuk menjalin kedekatan dengan pemerintah adalah dengan melalui komite aksi politik. Hal ini dapat dilakukan dengan membentuk komite-komite organisasi untuk melakukan aksi-aksi politik guna mempengaruhi kebijakan pemerintah.

b. Hubungan dengan komunitas

Hubungan komunitas atau yang biasa disebut dengan Community Relations merupakan strategi yang harus dijalankan oleh organisasi, yakni berkaitan dengan bagaimana membina hubungan baik dengan masyarakat sekitar (komunitas). Hal ini merupakan sebuah timbal balik bagi organisasi untuk memberikan kontribusi kepada masyarakat terkait keberadaannya di tengah-tengah lingkungan.

Menurut Jerold dalam Iriantara (2004:20), Community Relations merupakan peningkatan partisipasi dan posisi organisasi di dalam sebuah komunitas melalui berbagai upaya untuk kemaslahatan bersama bagi organisasi dan komunitas.

Mutual understanding adalah kunci adanya keberhasilan dari organisasi dalam menjalin hubungan dengan masyarakat sekitar. Di mana di dalamnya ada rasa saling memiliki, menghargai, serta berkesinambungan untuk memberikan kemanfaatan bersama.

Menurut Cutlip dan Center, dalam melaksanakan hubungan yang baik dengan komunitas, diperlukan adanya suatu kesadaran bagi organisasi untuk dapat mengetahui apa yang menjadi dambaan komunitas bagi kesejahteraannya. Dalam hal ini, apa yang diharapkan suatu organisasi sebagai salah satu sumbangan untuk kesejahteraannya itu, dan bagaimana menilai kontribusi tersebut. Berbagai hal yang menjadi kepentingan dari masyarakat tersebut, hendaknya dapat diperhatikan oleh organisasi, dimana kegiatankegiatan pengembangan masyarakat yang dilakukan idealnya selalu mengacu pada kepentingan komunitas sekitarnya. Upaya organisasi untuk membantu komunitas dalam mengupayakan terpenuhinya kebutuhan-kebutuhnnya akan menumbuhkan suatu persepsi positif anggota komunitas terhadap organisasi. (Effendy, 1999: 201)

\section{METODE PENELITIAN}

Jenis penelitian ini adalah penelitian kualitatif dengan metode studi kasus karena dalam penelitian ini akan berusaha memaparkan dan melacak urutan peristiwa/fenomena pada suatu lingkungan sosial dalam hal ini melihat bagaimana strategi yang dilakukan humas dalam menjalin hubungan baik dengan stakeholders external UAD.Studi Kasus merupakan penelitian yang nantinya diharapkan mampu memberikan uraian dan penjelasan komprehensif mengenai berbagai aspek seorang individu, suatu kelompok, organisasi (komunitas), program, ataupun situasi sosial. Peneliti studi kasus, berupaya menelaah sebanyak mungkin data mengenai subjek yang diteliti. (Mulyana, 2002:201).

Menurut Bogdan dan Bikien (1982), Studi kasus merupakan pengujian secara rinci terhadap satu latar atau satu orang subyek atau satu tempat penyimpanan dokumen 
atau peristiwa tertentu. Tugas seorang peneliti yang menggunakan metode studi kasus, adalah berusaha memperolah sebanyak mungkin data-data mengenai subyek penelitian untuk kemudian dianalisis.

\section{PEMBAHASAN}

\section{Manajemen Isu dan Publisitas}

a. Isu-isu yang berkembang mengenai UAD

Ada beberapa isu negatif mengenai UAD yang berkembang di masyarakat, beberapa diantaranya, misalnya: mengenai pembangunan kampus terpadu yang dinilai lamban, akreditasi program studi yang masih banyak terakreditasi B, kurangnya lahan parkir, maupun isu mengenai ketidaklayakan UAD mendirikan Fakultas Kedokteran.

Tidak hanya isu negatif sebagaimana di atas saja, namun isu-isu yang positif juga banyak berkembang di masyarakat luas, seperti: UAD merupakan kampus swasta dengan mahasiswa yang banyak, UAD semakin baik dan mengembirakan dalam hal prestasiprestasi yang didapatkannya, dan pemberitaan di media massa yang lebih banyak sisi positif dibandingkan sisi negatifnya.

b. Manajemen Isu oleh Humas UAD

Guna menanggapi isu-isu negatif yang berkembang di masyarakat, nampaknya beberapa strategi bisa dilakukan oleh Humas UAD, seperti: segera memberikan klarifikasi melalui jumpa pers, mencari tahu dari mana sumbernya dan mendalami masalah dengan seksama, serta dari sisi internal organisasi diharapkan juga segera memperbaiki dan mencarikan solusi agar tidak menganggu eksistensi organisasi.

c. Fungsi kehumasan UAD

Ketika diberikan pertanyaan mengenai fungsi kehumasan di UAD, mayoritas stakeholders external menyatakan sudah bagus. Hal ini dapat dilihat dari banyaknya kerjasama dengan media-media untuk meningkatkan publisitas UAD sendiri, dan cukup kooperatif dalam memberikan informasi. Hanya saja beberapa hal dapat dilakukan untuk meningkatkan fungsi kehumasan tersebut, seperti: perlu lebih aktif dan informatif dalam memberikan informasi-informasi kepada stakeholders external, dan perlu banyak berkunjung ke media-media lokal di Yogyakarta.

\section{Pola Komunikasi}

a. Dikenalnya Humas UAD di kalangan stakeholders external

Ketika ditanya mengenai seberapa kenal stakeholders external dengan Humas UAD mayoritas informan menyatakan sudah cukup mengenal Humas UAD. Melalui event-event yang diselenggarakan oleh UAD maupun Humas, para jurnalis media pun juga telah mengenal Humas UAD. Tidak hanya kenal secara personal bahkan, diantara informan juga menyatakan sudah cukup dekat dengan Humas UAD. Melalui tatap muka secara langsung, maupun pertemuan di social media mereka saling berinteraksi. 
Diterbitkan oleh Program Studi IImu Komunikasi

Universitas Ahmad Dahlan Yogyakarta

b. Akses komunikasi antara Humas UAD dengan stakeholders external

Jika selama ini akses komunikasi Humas UAD adalah desentralisasi, maka menurut pendapat para informan mereka lebih setuju apabila akses komunikasinya terpusat. Dengan sistem komunikasi terpusat, akses informasi akan lebih mudah mengingat hanya ada satu sumber yang mengirimkan pesan.

Menurut para informan, akses informasi juga tidak hanya dilakukan secara formal saja, namun juga informal. Dengan demikian akan ada kedekatan emosional antara Humas dengan para stakeholders external. Akses komunikasi juga seharusnya dilakukan secara kontinyu, tidak hanya saat ada event-event yang diselenggarakan UAD semata.

Terkhusus untuk media, akses komunikasi juga bisa dilakukan melalui jumpa pers, milis, media gathering, dan press realese. Dengan demikian kedekatan dengan media juga akan terbangun. Memperluas akses komunikasi juga perlu dilakukan oleh Humas UAD, dengan demikian nama besar UAD sebagai salah satu sumber ilmu pengetahuan juga akan lebih dikenal oleh masyarakat luas.

c. Adanya Humas Fakultas di lingkungan UAD

Adanya humas fakultas yang diharapkan dapat memaksimalkan fungsi kehumasan di UAD tentunya tidak lepas dari perhatian para stakeholders external. Menurut para informan dalam penelitian ini, adanya humas fakultas diharapkan akan mengangkat nama fakultas itu sendiri. Meskipun demikian, sistem komunikasi yang satu pintu tetap dirasa lebih baik oleh para informan. Dengan sistem komunikasi satu pintu, tentu akan memudahkan koordinasi antara stakeholders external dengan Humas UAD sendiri. Humas UAD, diharapkan dapat memback up kebutuhan komunikasi dan informasi para stakeholders external ini.

d. Relationship yang bisa dibangun antara Humas UAD dengan stakeholders external

Dalam kaitannya dengan relationship yang bisa dibangun Humas UAD, para informan menjawab bahwa yang terpenting adalah pola komunikasi yang kontinyu, terbuka, dan tranparan. Hubungan baik tentu akan terjalin dengan sendiri, apabila hal tersebut dapat dilakukan. Memastikan bahwa akses komunikasi bisa berjalan dengan baik, merupakan tanggung jawab Humas UAD. Oleh karenanya, menunjuk staff khusus yang diberikan tugas untuk bertanggung jawab guna menjaga hubungan baik dengan para stakeholders external (media), menjadi suatu hal yang perlu diperhatikan juga.

\section{Media Komunikasi}

a. Pengelolaan Media Komunikasi

Pengelolaan Media Komunikasi di UAD nampaknya masih belum maksimal. Hal ini dapat dilihat, misalnya; kurang updatenya berita UAD di website, galeri foto yang masih kurang, tidak adanya informasi/release kegiatan yang terpublish di dalam website.

Media komunikasi di lingkungan UAD selama ini tidak terintegrasi dengan baik, masing-masing unit berjalan sendiri-sendiri tanpa ada kontrol yang jelas dari UAD. Padahal semestinya, pengelolaan media komunikasi dapat dimaksimalkan dengan baik sebagai sarana soft promotion. 
b. Iklan UAD di Media Massa

UAD cukup sering memasang iklan di media massa, baik iklan resmi (iklan korporat), advertorial, maupun iklan baris. Diantara para informan yang beberapa kali telah melihat iklan UAD yang lebih bersifat image building, mereka menilai bahwa selama ini iklan-iklan yang dibuat UAD sudah cuklup baik.

Ke depan UAD hendaknya mampu melihat moment dengan baik, sehingga mampu memanfaatkan moment tersebut sebagai sarana untuk memasang iklan. Misalnya saja pada hari besar keagamaan, maupun hari besar nasional.

c. Pengelolaan Social Media

Sosial media menjadi salah satu media yang banyak dikonsumsi oleh kalangan anak yogya. Oleh karenanya memanfaatkan social media dengan baik tentu menjadi sebuah alternatif bagi pengembangan UAD. Sekarang ini Humas UAD diharapkan mempunyai social media sendiri, untuk media publikasi baik internal maupun external. Konten-konten informasi yang menarik dan mudah dipahami menjadi salah satu karakteristik pengelolaan social media yang bisa dilakukan.

d. Pengelolaan Media Luar Ruang

Media luar ruang seperti halnya Baliho juga menjadi salah satu media komunikasi yang dibangun oleh UAD. Selama ini Humas UAD kurang mempunyai andil untuk pengelolaan media luar ruang tersebut. Media luar ruang lebih banyak dimanfaatkan untuk penerimaan mahasiswa baru. Padahal sudah seharusnya, Humas UAD membuat media luar ruang sendiri sebagai salah satu sarana untuk membangun image positif, bukan hanya sekedar pendaftaran mahasiswa baru.

Dengan menampilkan desaign-desaign yang sederhana, namun mudah dipahami media luar ruang menjadi sebuah alternatif untuk promosi kampus. Ketika dimintai pendapat tentang bagaimana media luar ruang UAD selama ini, mayoritas informan menyatakan sudah cukup baik, informatif, dan selalu unggul dalam menerima mahasiswa.

e. Efektivitas Media Komunikasi

Banyak media komunikasi yang bisa dimanfaatkan untuk berkomunikasi. Setiap media komunikasi tentu mempunyai karakteristik sendiri-sendiri. Penggunaan media komunikasi hendaknya disesuaikan dengan target sasaran yang diinginkan. Terkhusus untuk para jurnalis media, mereka tidak hanya menginginkan adanya komunikasi melalui jejaring social saja (whatsapp, email, release, dst), akan tetapi juga menginginkan adanya pertemuan non formal yang rutin dilakukan, misalnya saja coffe morning. Dengan pertemuan tersebut diharapkan mampu menjalin kedekatan emosional antara Humas UAD dengan para jurnalis. Dalam pertemuan tersebut, bisa dimanfaatkan untuk sekedar ngobrol santai, diskusi mengenai isu-isu terkini yang sedang berkembang, maupun juga sosialisasi mengenai sebuah kebijakan di UAD.

\section{f. Pemanfaatan Media Komunikasi}

Media komunikasi akan lebih bermanfaat apabila bisa dikelola dengan baik. Ada kesan selama ini, media komunikasi di fakultas/prodi justru lebih aktif dibandingkan di tingkat universitas. Padahal seharusnya di tingkat universitaslah, sumber informasi utama. Tidak hanya mengoptimalkan fungsi media komunikasi semata, namun Humas diharapkan juga mampu membuat program-program kerjasama dengan media massa sebagai strategi branding UAD, misalnya; dialog interaktif di televisi, maupun radio. 
Diterbitkan oleh Program Studi IImu Komunikasi

Universitas Ahmad Dahlan Yogyakarta

g. Saran terhadap Pengeloaan Media Komunikasi

Ketika ditanya mengenai bagaimana pengeloaan media komunikasi UAD ke depannya, berikut beberapa saran yang disampaikan oleh stakeholders external: perlu adanya peningkatan kerjasama dengan berbagai sektor, memperluas penggunaan mediamedia komunikasi sebagai sarana promosi UAD, mencari strategi kreatif yang dapat menarik perhatian masyarakat luas, memaksimalkan media-media baru seperti halnya website dan sosial media, meningkatkan jaringan untuk branding UAD agar lebih menguat di masyarakat, meningkatkan jumlah publikasi di berbagai level media (cetak, radio, dan elektronik), lebih berperan dalam menyelesaikan permasalahan-permasalahan bangsa, memperbanyak publisitas dengan reaktif menanggapi isu-isu yang berkembang di masyarakat melalui pakar-pakar UAD, dan mengoptimalkan publisitas di berbagai pusat studi yang dimiliki UAD, misalnya: penentuan awal ramadhan, Pusat Studi Astronomi dan lainnya.

\section{E. KESIMPULAN DAN SARAN}

\section{Kesimpulan}

Berdasarkan penelitian yang telah dilakukan, peneliti mendapatkan kesimpulan sebagai berikut:

a. Dalam kaitannya dengan manajemen isu, Humas UAD diharapkan dapat lebih peka dalam melihat isu-isu yang sedang berkembang di masyarakat. Sehingga isu-isu yang ada bisa dimanfaatkan untuk branding UAD sendiri. Jika sekarang ini masih terdapat isu-isu yang kurang baik mengenai UAD, maka Humas diharapkan mampu mencarikan solusi untuk mengurangi isu-isu negatif tersebut, dan menggantikannya dengan isu-isu yang positif.

b. Dalam kaitannya dengan pola-pola komunikasi yang dibangun, Humas UAD diharapkan lebih informatif lagi dalam membuka akses komunikasi dan informasi, terlebih dalam kaitannya dengan media. Pola komunikasi yang dibangun diharapkan terpusat (satu pintu). Sehingga adanya staff khusus yang ditugaskan untuk menghandle hubungan media menjadi sebuah kebutuhan.

c. Dalam kaitannya dengan pengelolaan media komunikasi, Humas UAD diharapkan mampu mengoptimalkan media-media komunikasi yang ada. Baik media online (website, ataupun social media), dan media luar ruang (baliho, poster, leaflete, reklame, dll). Media Komunikasi sangat penting untuk branding UAD sendiri. Jika selama ini media komunikasi kurang termonitoring dengan baik (baik dari segi content maupun desaign), maka tugas Humas UAD untuk memonitoring hal tersebut. Membuat media-media social resmi UAD (official social media), juga diperlukan dalam hal ini. Mengingat selama ini unit-unit lah (fakultas maupun prodilah) yang justru lebih aktif.

\section{Saran}

Dalam penelitian mengenai strategi Humas dalam menjalin good relationship dengan stakeholders external ini, peneliti dapat memberikan saran-saran sebagai berikut: 
a. Mempertahankan isu-isu positif yang sedang berkembang dengan meningkatkan prestasi, serta mencari strategi yang tepat untuk menangani isu-isu negatif yang berkembang. Selain itu, Humas UAD diharapkan juga dapat lebih aktif dalam melihat isu-isu yang sedang berkembang dan kemudian memanfaatkan isu tersebut sebagai sebuat upaya untuk membangun image positif di masyarakat.

b. Humas UAD diharapkan lebih aktif dan informatif dalam memberikan informasi kepada stakeholders external. Media-media komunikasi yang ada, bisa dimanfaatkan untuk menanggapi setiap pertanyaan yang diberikan.

c. Pengelolaan media komunikasi hendaknya bisa lebih diperhatikan lagi. Jika selama ini, intensitas update informasi di media-media komunikasi perlu ditingkatkan, baik melalui website, maupun sosial media.

\section{DAFTAR PUSTAKA}

Alma, Buchari. (2007). Manajemen Pemasaran dan Pemasaran Jasa. Bandung: Alfabeta. Arikunto, Suharsimi. (2002). Prosedur Penelitian Suatu Pendekatan Praktek. Edisi Revisi V. Jakarta: Penerbit PT Rineka Cipta.

Belch, George E and Belch, Michael A. (2004). Advertising and Promotion an Integrated Marketing Communication Perspective.

Budiharsono, S. (2001). Teknik Analisis Pembangunan Wilayah Pesisir dan Lautan. Jakarta: Pradnya Paramita.

Hurriyati, Ratih. (2005). Bauran Pemasaran dan Loyalitas Konsumen. Bandung: Alfabeta.

Kotler, Philip. (2005), Manajemen Pemasaran Edisi Kesebelas Jilid 1; Jakarta: Indeks.

Kotler, Philip., dan Keller, Kevin Lane., (2007). Manajemen Pemasaran Edisi Kedua Belas Jilid 2; Jakarta: Indeks.

Nasir, Safar, dkk. 2015. Profil Mahasiswa Baru dan Efektivitas Promosi UAD. Lembaga Penelitian dan Pengembangan UAD: Yogyakarta.

Rd., Soemanagara. (2012). Strategic Marketing Communication. Bandung: Alfabeta.

Saladin, Djaslim. (2004). Manajemen Pemasaran; Bandung: Linda Karya

Singarimbun. (1995). Metode Penelitian Survei. Jakarta: LP3ES.

Sugiyono. (2008). Statistika Untuk Penelitian. Bandung: Alfabeta.

Uma, Sekaran. (2006). Metode Penelitian Bisnis. Jakarta: Salemba Empat. 